\title{
EXPLORING THE ROLE OF FORESTRY SECTOR ON ECONOMIC SYSTEM OF GUNUNGKIDUL DISTRICT IN 1993 - 2008
}

\author{
Mamat Rahmat ${ }^{1,2}$, Takahiro $\mathrm{F}^{3}$ and Noriko Sato ${ }^{3}$ \\ Received : 10 May 2012, Accepted : 19 September 2012
}

\begin{abstract}
This study was conducted to explore the role of forestry sector in the economic system of Gunungkidul district. The Location Quotient (LQ) Analysis, Income Multiplier Effect Value, and Klassen Typology Analysis were employed to analyze the role of the forestry sector. The data were regional income of Gunungkidul district and Yogyakarta Province from 1993 to 2008, including the economic crisis period from 1997 to 1998 . The result showed that forestry sector was an important sector in economic development of Gunungkidul district. LQ analysis indicated that forestry became a basic sector since pre-economic crisis period until post-economic crisis (1993 - 2008). Prior to the economic crisis, forestry sector generated the highest income multiplier effect value. However, the value dropped during and after the economic crisis. The economic crisis had an influence on the development pattern classification of forestry sector. Before economic crisis, forestry sector was classified as a developed sector (quadrant I) with the growth and shared to GDRP in Gunungkidul were higher than that in Yogyakarta Province. Meanwhile, since the economic crisis, forestry sector fell into the lower class as a stagnant sector.
\end{abstract}

Keywords: LQ analysis, income multiplier effect, Klassen typology, regional economic, privately owned forest

\section{INTRODUCTION}

Forestry sector provides significant benefit for regional economic development in Gunungkidul district. The benefit could be classified into direct and indirect benefit. The direct among others benefit includes commercial and non-commercial use of wood, rattan, resin, and bamboo, while, environmental services are classified into indirect benefit (IIED, 2003).

In regional economic development, regional income is predicted by calculating the aggregation of the direct output value in each economic sector. This aggregated income value is called Gross Domestic Regional Product (GDRP). The income of forestry sector calculates the aggregated value of the direct forest output such

\footnotetext{
${ }^{1}$ Forestry Research Institute of Palembang, Indonesia

${ }^{2}$ Corresponding author:mmt_rahmat@yahoo.com

${ }^{3}$ Kyushu University, Japan
}

as wood, rattan, resin, bamboo and leaves. The wood is a dominant product in forestry sector in Gunungkidul district.

There are two types of forest that supplies wood in Gunungkidul district: State Forest (SF, butan negara) and Privately Owned Forest (POF, butan rakyat). According to Utari (2010), currently the $\mathrm{SF}$ is deteriorating on its of wood supply, while the POF increases its supply and provides wood for local and regional need. According to the Gunungkidul's statistic figures in 2008, the contribution of forestry sector for the GDRP totally came from POF, in the forms of wood, bamboo, and charcoal supplies which the production respectively are: $69,136.67 \mathrm{~m}^{3} ; 2,633$ poles and 216.388 ton (Statistic Office of Gunungkidul district, 2008).

The POF has been developing since 1970s in Gunungkidul (Nawir et al., 2007). Initially, the POF was developed by government project to rehabilitate degraded lands and save water 
resources. Later, the expansion of POF in Gunungkidul district is motivated by the price of wood product, especially teak wood, (Rohadi et al., 2010).

Several studies on POF in various aspects have been conducted in Gunungkidul, such as the research conducted by Andayani (2005) and Milawati (2010). Andayani (2005) focused her research on the distribution of $\log$ and feasibility study of POF cultivation, while Milawati (2010) has clarified the people's income from agroforestry system in Mahogany-Teak-Gnetum pattern located in Patuk sub-district. Both studies were based on microeconomic sphere analysis, which were not presenting the role of POF in the regional economic development spheres of Gunungkidul district. Both research have proved the benefit of POF for people of Gunungkidul as individual (the POF grower), but they did not show the advantages of POF development for the whole Gunungkidul people. Therefore, the objective of this paper is to fill up the information gap by clarifying forestry sector's role in economic system in Gunungkidul district.

This study analyzed the role of forestry sector over middle term period from 1993 to 2008 . For the sake of analysis, the periods were classified into three periods: pre economic crisis (1993 1996), economic crisis (1997 - 1999), and post economic crisis (2000 - 2008). The objectives of this study were to clarify (1). the role of forestry sector by economic base theory; (2). the multiplier effect value of forestry sector; and (3). the development pattern of forestry sector by Klassen Typology.

\section{RESEARCH METHOD}

\section{A. Conceptual Framework}

Forests ecosystem produces various benefits including three main benefits of economic, ecological, and social. The POFs also produce those three main benefits. In economic aspect, POFs generate direct benefit by selling wood and non wood products. POFs also produce many indirect benefits on ecological and social aspects such as micro climate regulation, carbon sequestration, water supply regulation, soil conservation, air pollution reduction, watershed protection, nutrient cycling, as well as education and research.

This paper focuses on the economic benefit of POF. Economic benefit of forest in regional economic sphere is depicted as forestry sector income on GDRP. The income was calculated of direct benefit of forestry sector which in supply timber and non timber forest product. The analysis was carried out to find out the role of forestry sector in the economic system of Gunungkidul.

To achieve the research objectives were presented above, the widely used and simple tools in regional economic analysis were employed i.e. : Location Quotient (LQ) Analysis, Income Multiplier Effect Value, and Klassen Typology. According to Tarigan (2009), the utilization of these tools is important to determine the superior and inferior sector in an economic development. In LQ Analysis, the superior sector called as the basic sector. Basic sector means the sector which

Table 1. Development sector classification by Klassen Typology

\begin{tabular}{lll}
\hline $\begin{array}{l}\text { Development Sector } \\
\text { Contribution to GDRP }\end{array}$ & \multicolumn{1}{c}{ Ysi = Ysn } \\
$\begin{array}{l}\text { Development Sector } \\
\text { Growth Rate }\end{array}$ & Dsn \\
\hline Rsi $=$ Rsn & Developed Sector & Developing Sector \\
\hline Rsi $<$ Rsn & Stagnant Sector & Underdeveloped Sector \\
\hline
\end{tabular}

Source: Adopted from Sjafrizal (2008)

Rsi : Growth rate of forestry sector in GDRP of Gunungkidul District

Rsn: Growth rate of forestry sector in GDRP of Yogyakarta Province

Ysi: Contribution of forestry sector to GDRP of Gunungkidul District

Ysn: Contribution of forestry sector to GDRP of Yogyakarta Province 
generates more income than the same sector within the reference (larger) area. In this study, regional economic system of Gunungkidul district was analyzed and Yogyakarta Province was determined as the reference area. Then, Income Multiplier Effect Value was employed to scrutinize the multiplier impact of basis sector to the non-basic sector in the economic system of Gunungkidul. The Klassen Typology was examined to determine the position of forestry sector in the economic development stage of
Gunungkidul district (Figure 1). In this method, the forestry sector explored whether it categorized as developed, stagnant, developing, or under-developed sector.

\section{B. Data Collection}

This study used various data including 1) output value for each sector of Gunungkidul district and Yogyakarta Province, 2) total output for whole sector of Gunungkidul district and

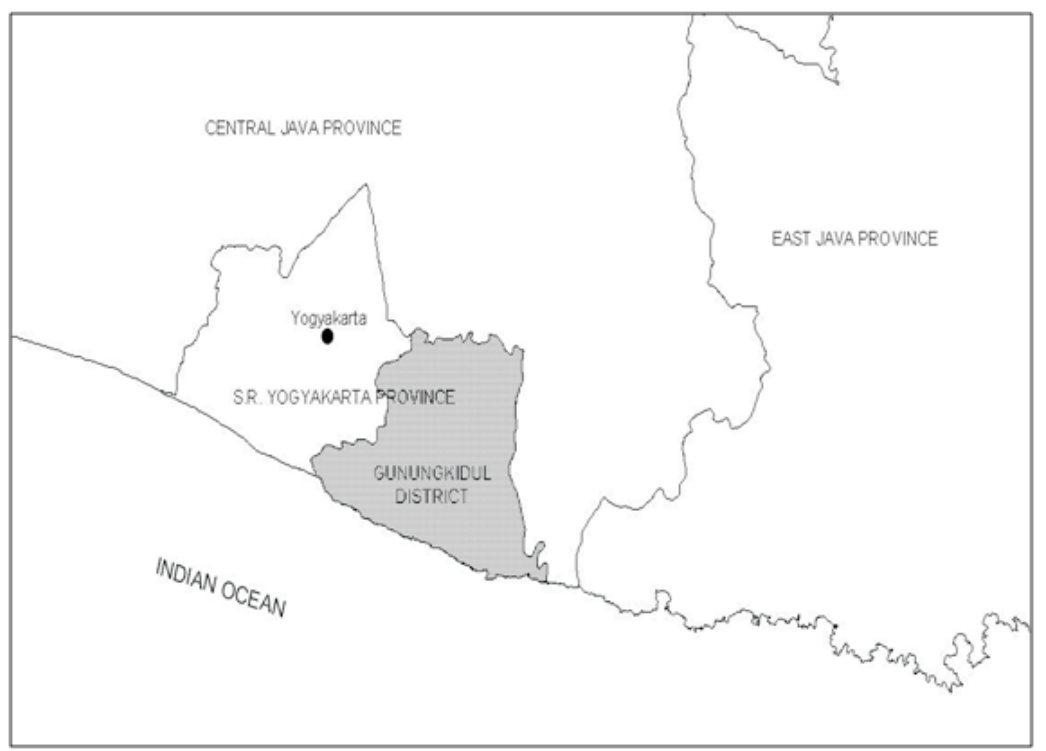

Figure 1. The situation map of Gunungkidul District

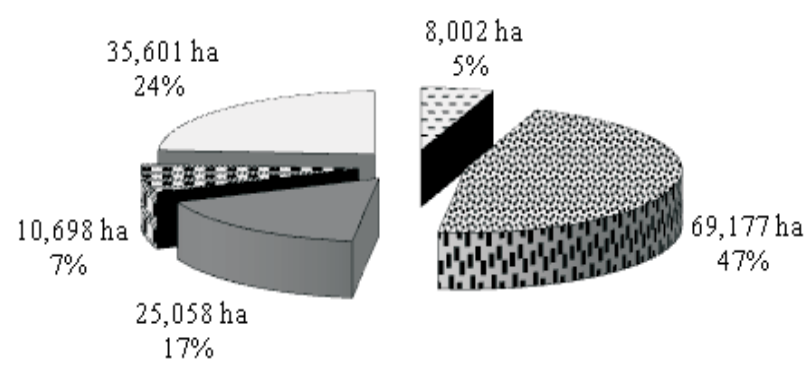

घRice field (5\%)
口Privately owned forest $(17 \%)$
$\square$ Non agricultural land $(24 \%)$

GDry agriculture land (47\%)

mOther agricultural land (7\%)

Source: Processed from Statistics Office of Gunungkidul District (2008)

Figure 2. Land use type of Gunungkidul District 
Yogyakarta Province 3) output growth for each sector in Gunungkidul district and Yogyakarta Province. The data was collected from Statistical Centre Agency publication.

\section{Data Analysis}

\section{Location Quotient (LQ) Analysis}

LQ Analysis was utilized to categorize forestry sector in economic system in Gunungkidul district into basic sector and non basic sector. While the basic sector indicate more than 1 (one) of LQ value, non basic sector indicate less than 1 of LQ value. The LQ formula employed in this study was referred to Bendavid (1974) with some modification. To calculate LQ value, Bendavid (1974) used employment level as a variable. Meanwhile, in this study, we were employed output value (sectoral income) as a variable. The similar modification also did by Kuncoro (2004) . Thus, the LQ value formula stated by:

$$
\begin{aligned}
& L Q \frac{v x i / v t}{V x j / V t} \\
& v x i= \text { output value for } \mathrm{x} \text { sector of Gunungkidul } \\
& \text { District } \\
& \mathrm{vt}= \text { total output value for whole sector of } \\
& \text { Gunungkidul District } \\
& \mathrm{Vxj}= \text { output value for } \mathrm{x} \text { sector of larger area, } \\
& \text { Yogyakarta Province } \\
& \mathrm{Vt}= \text { total output value for whole sector of } \\
& \text { larger area, Yogyakarta Province }
\end{aligned}
$$

\section{Multiplier Effect Value}

This study adopted coefficient of multiplier effect formula (Bendavid, 1974). The formula is expressed as below:

$$
\begin{aligned}
M & \frac{Y}{Y b} \\
\mathrm{M}= & \text { coefficient of multiplier effect value } \\
\mathrm{Y}= & \text { total output value of whole economic } \\
& \text { sector }
\end{aligned}
$$

$\mathrm{Yb}=$ output value of basic sector

\section{Klassen Typology}

According to Sjafrizal (2008), the Klassen Typology was classifies the economic development phase into four groups, and the groups are divided into four quadrants. The sector classification was determined by two factors: the sector contribution to GDRP (Ys) and the growth rate in development sector (Rs). Table 1 shows the sector classification by Klassen typology.

The first quadrant indicates the developed sector. This sector stage has two requisites: 1) the growth rate of forestry sector in local area/Gunungkidul district (Rsi) should be equal or more than the growth rate of the forestry sector in larger area (reference area/Yogyakarta Province) (Rsn) (Rsi $\geq$ Rsn), and 2) the contribution value of forestry sector to the GDRP in Gunungkidul district (Ysi) should be equal or more than the contribution value of forestry sector in Yogyakarta Province (Ysn) (Ysi $\geq$ Ysn). The second quadrant points out the stagnant sector, which prerequisites: Rsi should be equal or more than Rsn (Rsi $\geq \mathrm{Rsn})$; Ysi should be less than Ysn (Ysi<Ysn). The third quadrant indicates the developing sector, which prequisites: Rsi should be less than Rsn (Rsi < Rsn); Ysi should be equal or more than Ysn (Ysi $\geq$ Ysn). Lastly, the fourth quadrant points out the underdeveloped sector, which requisites: Rsi should be less than Rsn (Rsi $<$ Rsn); Ysi should be less than Ysn (Ysi $<$ Ysn).

\section{GENERAL DESCRIPTION OF GUNUNG KIDUL DISTRICT}

Gunungkidul district is one of districts in Yogyakarta Province. The district is located in the south eastern part of the province area. Geographically, the district is located between $7^{\circ}$ 46 $8^{\circ}$ 09' South Latitude, and $110^{\circ} 21^{\prime} 110^{\circ} 50^{\prime}$ East Longitude. The north and east side of district area is neighboring to Central Java Province, whereas the south side is bordering with the Indian Ocean (Figure 1).

The district area is around $1,485.36 \mathrm{~km}^{2}$ (Statistics Office of Yogyakarta Province, 2008), and covers the largest area among other districts in Yogyakarta Province. The area is about half of Yogyakarta Province area. The district area is classified into agriculture and non agriculture lands. According to the data presented by Statistics Office of Yogyakarta Province (2008), agriculture land covers 112,935 ha ( $76 \%$ of total district area) and the rest 35,601 ha (24\%) is non agriculture area. The agriculture area is divided into six land use types. Figure 2 shows the detail of the land use in Gunungkidul district. 
In the land use classification by Statistics Office of Gunungkidul District (2008), POF area is classified as non agricultural land. The total POF area in Gunungkidul in 2007 was 25,058 ha.

The POF in Gunungkidul district was dominated by teak (Tectona grandis). Other timber species are also common in the POF area, such as acacia (Acacia auriculiformis), mahogany (Swietenia macrophylla), sengon laut (Paraserianthes falcataria), trembesi (Samanea saman), coconuts (Cocos nucifera), trengguli (Cassia fistula), turi (Sebania grandiflora), glisidia (Glyricidia sepium), and bamboo. In addition, some fruit trees, such as mango (Mangifera indica), rambutan (Nephelium lappaceum), orange (Citrus spp.), papaya (Carica papaya) and banana (Musa spp.) are also commonly planted with mix cropping (KWML 2006).

In terms of forest condition in Gunungkidul district, while state forest area is decreasing, the POF area is increasing (Utari, 2010). According to Statistic Office of Gunungkidul, the total area of private forests was 25,058 ha in 2007 , or about 0.04 ha per capita. There were 685,210 inhabitants, and the average of the POF area were 0.14 ha per households (Statistic Office of Gunungkidul 2008). While the POF area per capita was constant from 2004 to 2007, the area per households dropped from 0.16 ha in 2004 to 0.14 ha in 2007.

\section{RESULTS AND DISCUSSION}

\section{A. Contribution of Forestry Sector to GDRP}

The share of forestry sector to GDRP fluctuated from 1993 to 2008 (Figure 3). During pre-economic crisis period (1993 - 1996), the contribution of forestry sector to GDRP was less than one percent. During economic crisis period (1997 - 1999), the share raised to near $10 \%$. Meanwhile, the share of agriculture sector dropped to below $30 \%$. This change of the share indicated that people cut down their trees to fulfill their need during economic crisis period. On the other hand, the income shared of agriculture sector dropped due to the decline of demand on agricultural goods.

\section{B. Basic Sector}

The analyzed data presented that LQ value of forestry sector from 1993 to 2008 was more than one (Table 2). The fact indicated that forestry sector was very important in economic system of Gunungkidul district. The economic crisis has not changed the role of forestry sector as a basic sector in Gunungkidul district.

Goods provided by basic sector was traded in local market and also in regional or national market. As a basic sector, forestry has a high

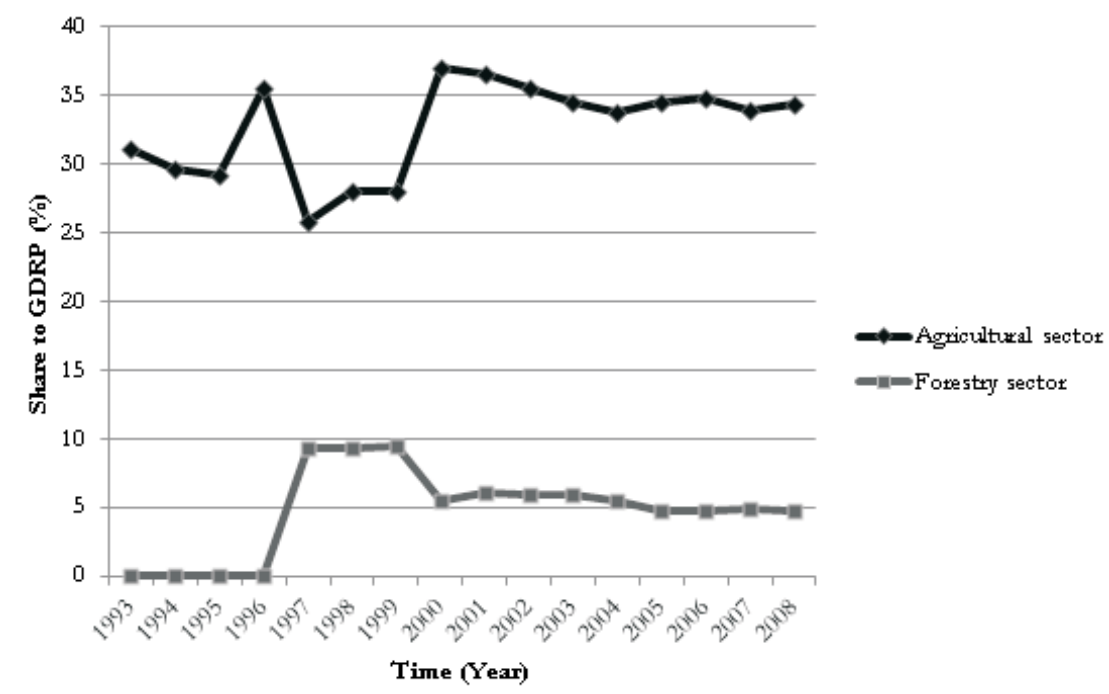

Source: Data processed

Figure 3. The share of forestry and agricultural sector to GDRP of Gunungkidul District in 19932008 
Table 2. LQ value of economic sectors in Gunungkidul District

\begin{tabular}{|c|c|c|c|c|c|c|c|c|c|c|c|c|c|c|c|c|}
\hline \multirow{2}{*}{ Sectors } & \multicolumn{16}{|c|}{ LQ Value by Year } \\
\hline & 1993 & 1994 & 1995 & 1996 & 1997 & 1998 & 1999 & 2000 & 2001 & 2002 & 2003 & 2004 & 2005 & 2006 & 2007 & 2008 \\
\hline Agriculture & 1.81 & 1.82 & 1.85 & 2.29 & 1.69 & 1.72 & 1.86 & 1.91 & 1.90 & 1.89 & 1.92 & 1.90 & 2.03 & 1.95 & 1.97 & 1.98 \\
\hline Forestry & 4.48 & 4.48 & 4.49 & 4.22 & 5.43 & 5.10 & 5.04 & 4.58 & 4.68 & 4.89 & 4.81 & 4.95 & 4.54 & 4.85 & 4.83 & 4.85 \\
\hline Mining and Quarrying & 1.25 & 1.26 & 1.39 & 1.28 & 1.31 & 1.43 & 1.46 & 2.98 & 3.01 & 3.01 & 2.96 & 2.91 & 2.87 & 2.79 & 2.51 & 2.51 \\
\hline Manufacturing Industries & 0.90 & 0.91 & 0.92 & 0.86 & 0.90 & 0.87 & 0.84 & 0.75 & 0.75 & 0.77 & 0.78 & 0.80 & 0.83 & 0.82 & 0.82 & 0.82 \\
\hline Electricity, Gas, and Water Supply & 0.39 & 0.40 & 0.43 & 0.28 & 0.36 & 0.35 & 0.32 & 0.47 & 0.49 & 0.48 & 0.48 & 0.53 & 0.55 & 0.54 & 0.56 & 0.57 \\
\hline Construction & 1.07 & 1.06 & 1.08 & 0.97 & 0.97 & 1.07 & 1.04 & 0.95 & 0.99 & 0.98 & 0.93 & 0.92 & 1.01 & 0.85 & 0.84 & 0.85 \\
\hline Trade, Hotel and Restaurant & 0.71 & 0.72 & 0.72 & 0.66 & 0.67 & 0.69 & 0.68 & 0.70 & 0.69 & 0.69 & 0.69 & 0.70 & 0.73 & 0.69 & 0.71 & 0.71 \\
\hline Transportation and Communication & 0.96 & 1.00 & 0.99 & 0.90 & 0.92 & 0.89 & 0.89 & 0.70 & 0.67 & 0.68 & 0.68 & 0.68 & 0.72 & 0.68 & 0.69 & 0.67 \\
\hline $\begin{array}{l}\text { Finance, Real Estate and Business } \\
\text { Services }\end{array}$ & 0.41 & 0.43 & 0.43 & 0.40 & 0.40 & 0.35 & 0.35 & 0.40 & 0.41 & 0.43 & 0.45 & 0.47 & 0.50 & 0.47 & 0.48 & 0.50 \\
\hline Services & 0.88 & 0.86 & 0.86 & 0.76 & 0.79 & 0.75 & 0.75 & 0.71 & 0.71 & 0.73 & 0.76 & 0.79 & 0.82 & 0.79 & 0.80 & 0.79 \\
\hline
\end{tabular}

Source: Data processed

potential to generate income by selling output to the other districts or to the regional market in Gunungkidul district. It indicated that output from forest sector was very important to fulfill human need in local area as well as larger area in Gunungkidul district (Yogyakarta Province).

\section{Income Multiplier Effect Value}

The income multiplier effect of forestry sector was relatively fluctuated. Before economic crisis period, the income multiplier effect value of forestry sector was the biggest in the economic system in Gunungkidul district. The value was more than one thousand, while the other ones were no more than sixty.

However, the value changed during and after ecocomic crisis that occurred in 1997. During these periods, the income multiplier effect value of forestry sector was dropped until ten. On the other hand, the value of others basic sectors were relatively constant. The income multiplier effect value of agriculture sector stayed constant at around three and mining quarrying sector also stayed constant at around fifty.

The income multiplier effect indicated that the income from basic sector could stimulate generating income from non basic sectors. As an example, the income multiplier effect value of forestry sector in 1993 was 1,382.93 (Table 3). These value means that when forestry sector generated income of US\$1,000.00, it could stimulate to generate income from non basic sectors until US $\$ 1,382,930.00$.

The process of generating income from non basic sector could be explained as follows. The basic sector produces output and trades it into regional market (larger market). The economic actors in Gunungkidul district gain more income from the trading. The economic actors will spend more income to fulfill human needs by consuming various product that also afforded from non basic sectors in the local area. The rising of consumption could stimulate non basic sectors to increase output.

The income multiplier effect value of mining and quarrying sector was higher than that of forestry sector as well as agricultural sector after economic crisis (Table 3). The implication of these values is that the developing mining and quarrying sector could generated more income from non basic sector. However, developing mining and quarrying sector should be noticed in terms of the negative environmental effect. Meanwhile, the developing of forestry sector

Table 3. Multiplier effect value of basic sectors on economic system of Gunungkidul District

\begin{tabular}{|c|c|c|c|c|c|c|c|c|c|c|c|c|c|c|c|c|}
\hline \multirow{2}{*}{ Sectors } & \multicolumn{16}{|c|}{ Income Multiplier Effect Value (US\$) by Year } \\
\hline & 1993 & 1994 & 1995 & 1996 & 1997 & 1998 & 1999 & 2000 & 2001 & 2002 & 2003 & 2004 & 2005 & 2006 & 2007 & 2008 \\
\hline Agriculture & 3.210 & 3.366 & 3.430 & 2.812 & 3.882 & 3.566 & 3.569 & 2.700 & 2.730 & 2.812 & 2.895 & 2.963 & 2.900 & 2.868 & 2.952 & 2.906 \\
\hline Forestry & $1,382.930$ & $1,455.856$ & $1,535.475$ & $1,723.907$ & 10.662 & 10.651 & 10.502 & 17.970 & 16.608 & 16.996 & 16.829 & 18.117 & 20.691 & 20.757 & 20.315 & 21.234 \\
\hline $\begin{array}{l}\text { Mining and } \\
\text { Quarrying }\end{array}$ & 54.740 & 54.421 & 50.330 & 57.035 & 57.442 & 55.277 & 54.572 & 38.530 & 39.531 & 41.237 & 43.522 & 46.030 & 48.858 & 49.782 & 52.704 & 55.379 \\
\hline
\end{tabular}

Source: Data processed 
Table 4. Forestry sector development classification according to Klassen Typology

\begin{tabular}{lccl}
\hline \multicolumn{1}{c}{ Analysis Period } & $\begin{array}{c}\text { Forestry Sector } \\
\text { Growth }\end{array}$ & $\begin{array}{c}\text { Forestry Sector } \\
\text { Contribution to } \\
\text { GDRP }\end{array}$ & $\begin{array}{c}\text { Klassen Typology } \\
\text { Class }\end{array}$ \\
\hline Pre-economic crisis & Rsi $>$ Rsn & Ysi $>$ Ysn & Developed sector \\
Economic crisis & Rsi $<$ Rsn & Ysi $>$ Ysn & Stagnant sector \\
Post-economic crisis & Rsi $<$ Rsn & Ysi $>$ Ysn & Stagnant sector \\
\hline
\end{tabular}

Source: Data processed

could provide positive environmental effect. For further, in comparison with agriculture sector, forestry sector is more promising to be developed in Gunungkidul district.

\section{The Structural Development Pattern of Forestry Sector}

The result of economic development pattern of forestry sector in Gunungkidul district is shown in Table 4. The forestry sector was classified as a developed sector during preeconomic crisis period. That pattern indicated that forestry sector rapidly grew and highly contributed to economic system in Gunungkidul district. The sector growth value and the sector contribution rate of forestry in Gunungkidul district were higher than that in Yogyakarta Province.

However, during and after the crisis period, forestry sector was down to stagnant level. This level indicated that the forestry sector growth rate in Gunungkidul district was less than that in Yogyakarta Province, yet the sector contribution in the District was higher than that in the province.

\section{CONCLUSION}

1. Forestry sector had a basic sector in economic system in Gunungkidul district since the preeconomic crisis period until post-economic crisis (1993 - 2008). It indicated that forestry sector was important for generating income on economic development in Gunungkidul district.

2. Before the economic crisis, forestry sector generated the highest income multiplier effect value. However it had been dropping since the economic crisis up to 2008.
3. The economic crisis influenced the pattern of sector forestry development in Gunungkidul district. Before the economic crisis, forestry was classified as a developed sector with featured: forestry sector growth and contribution to GDRP in Gunungkidul district were higher than that in Yogyakarta Province. Meanwhile, during and after the crisis, the forestry sector fell to the lower class as a stagnant sector, with feature: lower forestry sector growth but higher contribution to GDRP in Gunungkidul district than the growth and contribution of that sector in Yogyakarta Province.

\section{REFERENCES}

Andayani, W. 2005. Ekonomi pengelolaan hutan rakyat: Aspek kajian pola usaha tani dan pemasaran kayu rakyat. In: S.A. Awang, (Ed.). Kelangkaan Air: Mitos Sosial, and Ekonomi Rakyat. Debut Press, Yogyakarta.

Bendavid, A. 1974. Regional Economic Analysis for Practitioners: An Introduction to Common Descriptive Methods. Revised Edition. Praeger Publishers, New York.

International Institute for Environment and Development (IIED). 2003. Valuing Forests: A Review of Methods and Application in Developing Countries. International Institute for environment and Development, London.

Koperasi Wana Manunggal Lestari (KWML). 2006. Buku I dokumen pengajuan sertifikasi pengelolaan hutan berbasis masyarakat lestari (PHBML) unit manajemen hutan rakyat desa Girisekar, 
desa Dengok, desa Kedung Keris, Kabupaten Gunungkidul. KWML, Gunungkidul.

Kuncoro, M. 2004. Otonomi dan Pembangunan Daerah: Reformasi, Perencanaan, Strategi dan Peluang. Erlangga, Jakarta.

Milawati, N. 2010. Efisiensi agroforestry pola mahoni-jati-melinjo di Desa Nglanggeran, Kecamatan Patuk Kabupaten Gunungkidul. MSc Thesis. Faculty of Agriculture, Gadjah Mada University, Yogyakarta (unpublished).

Nawir, A.A., Murniati, L. Rumboko, C. Hiyama, and T. Gumartini. 2007. Portraits of rehabilitation projects in Indonesia. In: A.A. Nawir, Murniati and L. Rumboko (Eds). Forest Rehabilitation in Indonesia: Where to After Three Decades?. Center for International Forestry Research (CIFOR), Bogor.

Rohadi, D., M. Kallio, H. Krisnawati and P. Manalu. 2010. Economic incentives and household perceptions on smallholder timber plantations: Lessons from case studies in Indonesia, Paper presented at Montpellier Conference, 24-26 March 2010.

Sjafrizal. 2008. Ekonomi Regional, Teori dan Aplikasi. Baduose Media, Padang.

Statistics Office of Gunungkidul District. 2008. Gunungkidul in Figure 2008. Statistics Office of Gunungkidul District, Gunungkidul.

Statistics Office of Yogyakarta Province. 2008. Yogyakarta in Figure 2008. Statistics Office Yogyakarta Province, Yogyakarta.

Tarigan, R. 2009. Ekonomi Regional: Teori dan Aplikasi, Edisi Revisi. Bumi Aksara, Jakarta.

Utari, A.D. 2010. Strategi pengelolaan hutan negara berbasis keberhasilan pengelolaan hutan rakyat di Provinsi Daerah Istimewa Yogyakarta: Studi kasus di Kabupaten Gunungkidul. Doctor Thesis. Faculty of Forestry, Gadjah Mada University, Yogyakarta. 